\title{
Animal Welfare in Relation to Standards in Organic Farming
}

\author{
By Karl-Erik Hammarberg
}

Hudiksvalls distriktsveterinärstation, Malnvägen 2, S-824 50 Hudiksvall

\begin{abstract}
The new EU-regulations on organic farming (1804/1999) are also influencing the animal welfare. A lot of positive regulations is to find, but also regulations that seen to mind more about the general public and customer and their view on organic farming, than the health and welfare of the animals.

The paper specially focus on the impact of the regulations and the recommendations that phytotherapeutic essences and homeopathic products take precedence over the so called chemically-synthesised allopatic veterinary medical products, and that the use of the same is prohibited for preventive treatments. Key questions here are the lack of scientific evidence concerning homeopathy in animals, and that Swedish veterinarians are not allowed to work with homeopathy.

Differences in interpretation of the regulations between animal owners and veterinarians will also be discussed. What is a disease that needs treatment? Who is to decide about the treatment? Parasitic infections are discussed as an illustrative example.

Other consequences of the regulations concerning the animal welfare are problems in certain geographical zones, for instance subarctic areas where necessary crops are impossible to grow.

Animal transports and splitting mother-offspring are briefly discussed as future problems to be handled in the regulations, and the paper ends by presenting the need of regulated herd health control programs in organic husbandry, which can detect and focus on welfare and production problems. The organic movement is not static, and must not be so.
\end{abstract}

Organic farming, EU-regulation, animal welfare, homeopathy, allopathy, treatment, transport, health care.

\section{Introduction}

Ever since our human ancestors began to abandon the life as hunter gatherers and enter into an existence based on permanent settlements living from agriculture, animal husbandry has been a natural part of producing food. Through animals, nutrients, indigestible for humans, e.g. grass and leaves, could be converted to edible proteins, energy, fat and minerals. In our colder climate zones these nutrients could be stored in the animals until they were needed. It is no exaggeration to state that animal husbandry has been a necessity for man in order to be able to survive in cold climate zones.
Agriculture developed to begin with slowly. Initially by slash and burn methods, later with hay making agriculture leading on to farming with crop rotation. During the last 80 years, in Sweden especially during the last 50 years, the use of artificial fertilisers which now, with increased political support and a maturing view on agriculture, is changing towards organic farming. The main reason for this is the last decades focus on the damage caused by artificial fertilisers and the impacts of the circulation of nutritive substances on the environment. With the increase in industrial agriculture fol- 
lowed a large-scale animal farming, focusing on maximum production output, not always favourable to the animals.

Personally I grew up on a farm and later worked as a veterinarian in rural practice. This has given me the opportunity to follow the rapid development in animal farming during the last 50 years. I have even been a part in this "progress". To partake in this development does not necessarily mean that one sympathises with all that is seen, or with all that has been done. It has, especially during the last decade, become increasingly clear to me that a part of my work has been to act as a "cleaning lady" after the advisers and companies that has led the development in animal farming. Technicians have introduced ventilation systems and constructed cubicles and pens. I have had to deal with calf pneumonia and mastitis. Feeding advisers have created food for animals and I have had to take care of disturbed stomachs, enteritis and distorted immune systems. Economists have recommended large-scale farming and the spreading of contagious diseases have been left for me to attend.

To become aware of the fact that I, by hopefully being a skilful vet, have supported this development, and maybe even helped to maintain this practice of which parts should have been abandoned a long time ago, has increasingly frustrated me.

With this background I see organic animal farming as one of several possible ways to leave this form of animal husbandry behind us, a husbandry that does not put the animals and their needs in focus.

Organic animal farming has in itself been in existence all the time parallel to this development, but it was not until the 1970:s that it began to be formalised. Organic products had to be certified, in one way or another, and give the customer information and knowledge of what it meant to buy "organic". Gradually also the politicians began to catch the organic trend and started to support it with financial subsidies. Targets were set up. One was the $10 \%$ level. This meant that by the year 2000, $10 \%$ of Swedish farming was to be organic.

The rest is well known to you all. An international umbrella organisation, IFOAM ( International Federation of Organic Agriculture Movements), was set up with criteria to define, among other things, organic animal husbandry. Control work began in every participating country supervised by its central authorities. In my country the Swedish Board of Agriculture has appointed KRAV (Kontrollföreningen för ekologisk odling) and the Demeter organisation to set the directive for organic production and to control the suppliers.

\section{EU-Regulation 1804/1999 and animal welfare}

Organic animal husbandry is not static. It is under continuous development. Many of the initial blunders and mistakes have in co-operation with others, among them the vets, been altered and corrected and work continues. In the year 1999, EU decided that certain common rules were to be in force within the whole common market. I am referring to Regulation 1804/ 1999. It is from the basis of this regulation that I want to give some veterinary comments and thoughts on organic animal farming.

We must presume that the regulation has been introduced to foster and improve the life of the animals. This is, however, not obvious to me. The same thoughts have been put forward in some papers from the Network for Animal Health and Welfare in Organic Agriculture, NAHWOA. No, the decisions behind some of the directives in the regulation are more to satisfy people's expectations and wishes on organic products and to keep the confidence in organic produced products high. No chemicals, no medical drugs. 
Many of the regulations are clearly to the advantage of the animals and their general welfare, e.g. demands of prolonged access to milk and increased possibility to live in an environment which favours natural behaviour. These and other EU regulations are to be praised, but others really have to be debated.

As a veterinarian I believe I can do better for animal welfare. Not only by giving assistance with setting up regulations to foster animal welfare, but also by bringing to your attention the weaknesses and discrepancies I see through my veterinary coloured glasses.

We should also bear in mind that some people start organic farming from a subjective image of an organic ideal and not from sound knowledge of agriculture. This does perhaps not lead to any serious consequences when it involves plant growing, but when it is associated with animal farming the consequences can be serious.

There is nothing in the organic regulation that stipulates any knowledge on how to run and manage an animal farm. It does not even state to strive for as natural a life as possible for the animals. The real nature is far too tough for that.

So let us take a look at some of these new regulations where, as a vet, I am of the opinion that animal welfare might be affected in a negative way.

"The use of chemically synthesised allopathic veterinary medicinal products or antibiotics for preventive treatments is prohibited." (1)

Here I would like to debate the fear of using chemicals or medical drugs. I find among some organic farmers that this regulation tends to support their subjective opinion. The Swedish animal welfare legislation, which is alleged to be the toughest in the world, claims that animals have to be protected against diseases. My inter- pretation of the EU-regulation is, however, that you are not allowed to protect animals from diseases when there are no other ways left but using chemical "allopathic" products. In my view the regulation here leaves the welfare of animals in the hands of the general public's and the customer's opinion on organic farming. Let me give you some examples:

In the North of Sweden attacks from gnats and mosquitoes can be deadly to animals. When these insects flutter about, humans, even the organic farmer protects himself with chemical repellents, or tight fitting clothes. Animals on conventional farms are protected with chemicals, e.g. spot on's, but animals on organic farms are denied this protection, they are unable to run away from their paddock or "cover themselves with clothes". When you see animals attacked by gnats and mosquitoes, you realise they do suffer badly. I have on many occasions seen animals killed in this way.

Another example is tick born diseases. There are chemical protectors on the market, but it is unclear if they can be used prophylactically on organic farms without losing the organic status. Some tick born TBE-viruses can even spread via the milk from goats to humans if the milk is used in a non pasteurised state. (2)

The same thing can be said about Paraphilaria. There is no organically acceptable way to protect cattle against such fly attacks if you follow the EU-regulation. (1)

And, what about Haemonchosis in sheep and scabies in pigs? The eradication programme in conventional farming might leave only the animals bred in organic farming to suffer from these parasites and spread them.

There is also a need to make clear if vaccines are seen as allopathic drugs. This includes the vaccines where its manufacturing is a result of genetic engineering. In my opinion vaccination must be permitted and used in animal disease control and welfare programmes. 
Another thing that concerns me and many Swedish veterinarians and farmers is the ban on the use of synthetic vitamins in ruminant food. These additives are necessary and important in our Nordic climate with short grazing seasons and long, dark winters. The result might be lack of vitamins in high producing animals that can, among other things, affect their resistance against diseases. It can also have an affect on the human customer who prefers to drink organic milk. What about the vitamin E and selenium additives that we find is needed in selenium deficient grazing and harvesting areas? How about pain killers to animals in pain? What signals do parts of this EU-regulation send to the consumers?

For me as a veterinarian it is in this situation more important to protect the animals than the customers and consumers.

A consequence of the regulation, that does not immediately spring to mind, is that organic farms can serve as reservoirs for diseases which can be kept under control by the prophylactic use of allopathic drugs. Paraphilaria has, for instance, been mentioned. In conventional animal farming you can control the multiplication and spreading of parasites by using ear-tags with repellents, but an organic farm is not allowed to use these repellents. The parasite can thus survive and multiply there, with the result that the farms neighbouring such an organic farm have to continue to use chemical ear-tags more then if the organic farm had not been there. The result might be that a regulation aiming to reduce chemicals will lead to increased use when you look at the total effect. What will be the customer's reaction to organic farming when they hear that the organic animals are the only ones suffering from parasite problems?

\section{Sick or injured animals must be treated}

The EU regulation gives an example on how to maintain good and healthy conditions among the animals. This is great. But what happens when an animal gets sick or hurt regardless of this? What does the regulation say then?

"If, despite of the above preventive measures, an animal becomes sick or injured it must be treated immediately, if necessary in isolation, and in suitable housing". (1)

So sick and diseased animals are to be treated. So far so good, but we still face a problem here. When is an animal sick and what should the treatment be? I am not so sure that what a veterinarian claims to be a disease or a welfare problem is judged in the same way by the animal owner. In Sweden KRAV is absolutely clear on this matter. The veterinarian's point of view is valid. But we still face problems here. Let me just mention sheep suffering from endoparasites. When are they sick and what is natural?

We face the same problem when it comes to the treatment. The animal owner might prefer an alternative treatment to the one the veterinarian in a given situation believes to be the best, most effective and even necessary.

\section{Homeopathic treatment and welfare}

When it comes to treatment of sick animals the new EU-regulation puts restrictions on the vet's alternatives to act. I am referring to the following:

"Phytotherapeutic (e.g. plant extracts [excluding antibiotics], essences, etc.), homeopathic products (e.g. plant, animal or mineral substances) and trace elements and products listed in Part C, section 3 of Annex 11, shall be used in preference to chemically-synthesised allopathic veterinary medicinal products or antibiotics, provided that their therapeutic effect is effective for the species of animal, and the condition for which the treatment is intended". (1) 
The first part, about phyto-therapy and homeopathy has of course as a background that animals must be kept in a way which reduces disease problems and that the use of chemically-synthetic drugs is to be reduced as much as possible.

One interpretation of the regulation, at least in Sweden, is that anyone except a veterinarian is preferred to administer to sick animals on an organic farm, as Swedish vets are not allowed to use homeopathy and phyto-therapy. We must work only with methods based on science and proven experience. The mentioned therapies, especially homeopathy, do not satisfy this demand. There are thousands of reports on homeopathy, most of them bad or very bad, when seen through the eyes of science. However, there is still no proof that the homeopathic fundamentals "alike cures alike" and "potensation increases the effect" are true.

Funnily enough, you can interpret the regulation in quite a different way. By concentrating on the second part of it, "provided that their therapeutic effect is effective for the species of animal, and the condition for which the treatment is intended". I have not yet found any reports or tests giving me necessary information on this.

There are also other EU directives which can be interpreted that homeopathic drugs must be registered the same way as ordinary medical drugs in order to be allowed to be used in food producing animals (4).

I have in many different ways tried to clarify the situation to myself. What does it mean to me as a veterinarian and to the farmer? But so far I have been unsuccessful. Many things, also those concerning animal welfare, are still unclear to me. Those who believe in homeopathy understand and read published reports in their favour. The non-believers have another interpretation. But face the facts! There are no scientific indisputable reports that can support the positive and controllable effects from homeopathy in medical treatment of animals.

A consequence hereof has already been mentioned. Organic animal farming gets a reputation of not treating sick animals in an appropriate way. This can influence the consumer's view. Should this be so, the result of this regulation will be directly opposite to what is was intended.

In reality, I do not think the regulation will have any greater effect on the individual farmer. Those who are believers in homeopathy will continue to believe in it and treat sick animals as before. Those who do not believe in it will not change their minds as a result of the regulation. However, in the eyes of Swedish veterinarians and zoologists the EU-decision is more than astonishing. We have already now examples from both the organic and the conventional farming world where animals have suffered and even died when the farmer has chosen homeopathic treatment before traditional veterinary medicine (3). And we have seen the spreading of a contagious disease, BVD, through an homeopath. I believe that sooner or later, once reported to the police, this matter will end up as a court case where the charge will be that homeopathic treatment leads to undue suffering of animals. We will then finally get a judicial verdict on what is valid.

I really want to underline that I do not wish to glorify the use of chemical drugs and medicines with this paper. We shall of course strive for animal husbandry built on optimal environmental conditions. Feeding, genetics and care with the minimum use of drugs, but when the need arises they shall be used. This need shall, in my opinion, be decided by a veterinarian who has full knowledge of organic animal farming. With this I mean a vet who can see animal problems against the background of environmental influences, organic feeding, breeds, genetics, animal behaviour and other considerations. In other 
words a vet with an holistic view. We need a vet who can see further than just infectious matters as a background to the problem. But sometimes even infectious agents have to be considered.

\section{Maximum number of treatments}

The regulation states that animals loose their organic status if they are treated 3 times or more with chemical-synthetic allopathic drugs or antibiotics within one year. I have still no experiences of the consequences. Of course I see the risk that organic animal owners, when facing the choice between another allopathic treatment with possible loss of organic status and all its consequences, or no allopathic treatment at all, hope that the animal will get well anyway. Or will choose another treatment. Painkillers have been mentioned. But I hope that the animal owner who has already treated an animal twice during this period thinks more of the animal than the organic status. As I have understood it, the last word on this matter has still not been spoken.

\section{Separating mothers from their offspring}

I can see more than just medical problems when I consider animal welfare in the organic farming. I can also give you some ethological aspects on what I see, aspects I hope will be taken into consideration in a future regulation. Let me give you some examples:

In both conventional and organic dairy farming it is common to separate mother and calf already after a few days. This separation is very unnatural. Everybody who have heard a mother and calf calling for each other after a separation knows we should try to find a system where it would be possible for calves to stay longer with their mothers, stepmother or other adult cows. Research at the Agricultural University in Skara, indicates that such a system is feasible. The reason for separating mother and calf is, as you know, that the mother's milk is to be used for other purposes. However, the research mentioned, shows that it is possible to have the calf with its mother longer without any considerable loss of bulkmilk. The cow produces more milk when the calf suckles. My view is that we should start planning for systems where the calf has increased access to its mother (or stepmother) for longer and more often than is common today. The calf could be together with its mother a couple of times every day, or spend parts of the day or night with her.

Another example we can look at is the common separation of herds of sheep into groups, the purpose being to be able to feed every animal after their needs. A sheep herd actually consists of a number of small herds with mothers and daughters sticking together. To be able to feed the animals right we break up these social groups and put the animals in different pens. In nature this works without the groups being separated. I believe it is possible to find feeding systems where we do not need to separate the family groups as we do today. I have seen an organic sheep farmer with 35 ewes solving this problem brilliantly. They use a feeding system where the animals have free access to good hay and silage plus concentrate feeding in a way that gives also the younger ewes and lambs plenty of space to eat. It is worth a try to find similar systems for larger flocks.

\section{Tied up cows}

We need a further debate with regards to the tying up of cows. According to organic regulations the cows shall be given possibility to move, but there are situations when such motion causes more stress to the animal than when they are tied up. Consequently I do not recommend tied systems, just that we still do not have all relevant information and know-how about free walking systems. 


\section{Give the animals something to do}

We have over the years learnt a lot about how to put animals in houses, fences, pens, cubicles and feedlots. But still we do not give them anything to do, something for their curiosity, motoric training and playfullness. I wish that in the organic regulation there were some demands on this, for instance some differences in heights in their area, something to play with for instance balls or tires hanging from the ceiling, drag some bushes or cut down trees into their pens, or give them the possibility to really search for food. Give them something to do in a boring life situation. The organic animal farming should be forerunners here.

This is what I call animal welfare.

\section{Geographical restrictions}

I have above in this paper, in connection with gnat attacks, mentioned cold climate zones. A substantial part of the fodder, on average about $50 \%$, has to be harvested on the home farm. This means that farms geographically located outside what can be called the farming limit are excluded from organic farming, despite the fact that mountain farming of, for instance, cattle and sheep can be very friendly to the animals and the environment.

It can also be very difficult to grow grain for pigs and to get straw. The demand on outdoor living, or as close to outdoor living as possible, can cause problems with, for instance, frostbites on pigs or lamb ears in the sub arctic parts of Scandinavia. The regulation should be more flexible and adapt to local situations but still be based on an organic thinking. The regulation can, as it stands today, cause geographical restrictions on organic animal farming. If the new EU-regulation had been written by individuals with knowledge of organic matters and interested, practising skilful farmers from northern thinly populated areas of Europe, it would surely have looked different in many aspects.

\section{Transports to slaughter}

And so the time comes for slaughtering. According to general organic regulation, animals shall be slaughtered in approved and controlled abattoirs or slaughterhouses.

Against the present background of the closing down and centralisation of slaughterhouses, organically farmed animals have to be transported longer and longer distances, ( but not exceeding the Swedish legal maximum of 8 hours transport) sometimes bypassing non approved slaughterhouses. In many cases this is neither organic nor animal friendly. To me it goes without saying that organically farmed animals should be slaughtered at the nearest slaughterhouse. Most of all I would like to have them slaughtered on the farm or at a nearby approved small farm slaughterer.

To favour such a scheme I wish that central authorities would increase the number of animals accepted for slaughter in such small farm slaughterers. This is possible within the EUregulation. Such a decision would shorten the transit time and perhaps also improve the economy for small farm slaughterhouses.

Another way to go forward, is to accept the same veterinary inspection of the animals as when inspecting deer in deer farms at slaughter, or the inspection of game (moose, bears) for hunters. However, other statutes in the EU-regulation might not accept this 'modus operandum'.

\section{Animal health care service}

There are organic farmers who believe that the natural life is always best for the animal. That is not true. Nature is cruel. The natural death rate is in nature very much higher than the one acceptable to normally controlled animal farms. The aim is to keep diseases and production problems, which have turned out to be the cause of serious problems in organic farming, under control. I wish that organic farms had some sort 
of animal health care service within their regulation. This can be carried out either with the help of already existing animal health services, or by establishing a new health control programme within the organic organisations, with the help of veterinarians. Such a health care programme can look at environmental factors, parasite control, production results, slaughter results, post mortems etc. All with the end purpose of finding and determining the factors and weaknesses which influences animal health.

An animal health care programme must have a built in prophylactic work facility with effective methods to solve problems when other avenues have been exhausted. This must include the ability to use chemical-synthetic allopathic drugs, for instance, effective de-worming methods and vaccines. This is one of the fundamental aspects of animal health care. Strategic use of prophylactic measures is an advantage for the whole herd in stead of just being bound to a late treatment of single, sick individuals. A clarification with perhaps an alteration to the regulation in order to adapt to reality is desired. A positive consequence of an organised animal health care service within the organically run farming industry is that the buying of animals, when necessary, would be safer from an animal health point of view. Only buy from farms on the same or a higher level within the health care service program.

\section{The organic movement must not remain static}

After having said all this, there might be listeners who judge me as negative to the concept of organic farming. This is wrong. Critical on some points maybe, but basically very positive to an organisation opening doors to an animal husbandry more on animal terms than what we very often see in conventional farming.

More and more reports show that the animal health status on most organically run farms is satisfactory and thereby making it possible to maintain good production. There are, however, some exceptions, which perhaps will be discussed here by other speakers. The organic movement must seriously continue to tackle these situations.

I also respond very positively to the politicians who with their decisions open the possibilities for organic farming to compete and survive in a world where mass production is an economic advantage. If organic farming is not given the incentive, support and the economic capability to compete with the big mass producing organisations, the positive trend for organic farming will soon be broken.

The criticism I present here is meant to be positive. My talk here is meant to highlight a situation where we, unless we start working on them today, might face difficulties in the future. There are still bits and pieces to look at and work for, before we find a form of animal husbandry that is primarily based on the animal's needs. But I am optimistically hopeful as long as I can see the direction in which the organic movement in general is going today.

The organic movement is not static, and must not be so.

\section{References}

(1) EU-Regulation 1804/1999.

(2) Personal communication, State Veterinary College, Lithuania.

(3) Ekesbo, I. (2000) Förekomst och konsekvenser av homeopati på husdjur. Svensk Veterinärtidning, 52, 871-880.

(4) EU-regulation 1992/74.

\section{Sammanfattning}

Den nya EU-förordningen (1804/1999) om ekologiskt lantbruk påverkar också djurskyddet. Förordningen innehåller mycket som är positivt för djuren, men här finns också regler som mer tar hänsyn till allmänhetens och kundernas förväntan på ekologisk djurhållning än på djurens hälsa och djurskyddet. Artikeln tar bl.a. upp den reglerade rekommendatio- 
nen att homeopati och örtmedicin skall föredras framför traditionell skolmedicin, och att den senare inte är tillåten i förebyggande syfte.

Väsentligt här är bristen på vetenskapliga bevis och att svenska veterinärer inte får arbeta med sådana behandlingar. Också problem med ekologisk djurhållning i subarktisk klimatzon tas upp.

Ibland skiljer sig djurägarnas och veterinärernas tolkning av EU-förordningen. När är djuret så sjukt att det behöver behandlas? Vem beslutar om hur djuret skall behandlas, och med vad? Parasitangrepp diskuteras som exempel.
Att reglering av mängden hemmaproducerat foder försvårar ekologisk djurhållning för fjällgårdar diskuteras.

Slutligen tas också upp tankar kring framtida problem som borde regleras i ekologisk djurhållning. Hit hör djurtransporter och skiljandet mellan mor och avkomma. Artikeln avslutas med en rekommendation att ekologisk djurhållning borde omfattas av någon form av djurhälsoprogram genom vilket djurskyddsproblem och hälsoproblem kan detekteras. 